\title{
Censos e favelas cariocas: evolução de um conceito censitário ${ }^{1}$
}

Censuses and slums: evolution of a census concept

hitps://doi.org/10.1590/1982-02672020v28e23

\section{RAFAEL SOARES GONÇALVES²}

https://orcid.org/0000-000 1-8887-8931

Pontifícia Universidade Católica do Rio de Janeiro / Rio de Janeiro, RJ, Brasil

RESUMO: $O$ presente artigo procura levantar a evolução do conceito censitário de favelas desde o censo do Distrito Federal de 1948 até o último censo nacional de 2010. Não se pretende discutir especificamente os dados quantitativos obtidos pelos recenseamentos, mas, de um lado, retraçar a evolução das definições censitárias dos espaços favelados no decorrer dos séculos XX e XXI e, por outro lado, compreender como os serviços nacionais de recenseamento adaptaram suas formas de atuar para levar em consideração as especificidades desses espaços. Em ambos os casos, questionamos como o caso das favelas cariocas se tornou um modelo para pensar os bairros informais no país.

PALAVRAS-CHAVE: Favelas. Conceito censitário de favelas. Evolução dos recenseamentos.

ABSTRACT: This article aims to survey the evolution of the census concept of favelas from the Federal District census of 1948 to the last national census of 2010 . It is not intended to discuss specifically the quantitative data obtained by the censuses, but, on the one hand, to trace the evolution of the census definitions of favela spaces during the 20th and 21 st centuries and, on the other hand, to understand how the national census services adapted their ways of acting to take into account the specificities of these spaces. In both cases, we question how the case of Rio's favelas became a model for thinking the informal neighborhoods in Brazil.

KEYWORDS: Favelas. Favela's census concept. Censuses evolution.

\begin{abstract}
1. Esse artigo foi realizado com recursos de projetos obtidos junto ao CNPq (Processo $\left.\mathrm{n}^{\circ} 420923 / 2018-7\right)$, a Capes (Processo $n^{\circ}$ 88881.310222/2018-01) e à FAPERJ (Jovem Cientista Processo ${ }^{\circ}$ E-26/203.174/2017).

2. Advogado e historiador. Doutor em História e Civilização pela Université Paris Diderot. Pós-doutor em Antropologia pela École des Hautes Études en Sciences Sociales. Professor associado do Departamento de Serviço Social da Pontifícia Universidade Católica do Rio de Janeiro. Pesquisador CNPq e Faperj. Coordenador do Laboratório de Estudos Urbanos e Socioambientais (Leus) e editor científico da revista $O$ social em Questão. E-mail: <rafaelsgoncalves@yahoo.com.br.>
\end{abstract}


3. Martin (2016, p. 6).

4. Cf. Desroisières; Kott (2005).

5. Martin, op. cit., p. 7.

6. Senra (2019, p. 412).

7. Ibid., p. 413-414.

8. Cf. Gonçalves (2013).

\section{INTRODUÇÃO}

Os critérios de quantificação empregados nos recenseamentos não possuem nada de natural ou de evidente. Um emaranhado de questões emerge da análise dos conceitos utilizados para designar locais e quantificar grupos. Não há obviamente naturalidade ou transcendência na produção dos dados e esses materializam valores, escolhas e arbitragens subjacentes a essas categorias, nomenclaturas e critérios. ${ }^{3} \mathrm{Os}$ instrumentos quantitativos não são apenas instrumentos de comprovação científica, mas também instrumentos de coordenação e de governo. ${ }^{4}$

Assim, governar através dos números não é superar as questões morais, políticas ou econômicas, mas sim, muitas vezes, ocultá-las por instrumentos neutros e racionais. É mais sutil e consistente encobrir escolhas e posições políticas em instrumentos apresentados normalmente como objetivos e, por consequência, supostamente indiscutíveis. ${ }^{5}$ As estatísticas trazem informações sobre a população e suas relações sociais e econômicas existentes no espaço, subsidiando, através de dados, a formulação de políticas públicas. Desse modo, elas são uma forma de saber e uma fonte de poder. ${ }^{6}$

A compreensão histórica dos processos de definição, inclusão e exclusão das chamadas categorias de classificação estatística se manifesta, sem dúvida, como um horizonte bastante fecundo para as pesquisas históricas sobre as relações entre Estado e sociedade. Trata-se, assim, de compreender as classificações empreendidas e as metodologias aplicadas às mais diversas produções estatísticas, de forma a pensar politicamente o que elas significam. ${ }^{7}$

$\bigcirc$ presente trabalho se volta, mais especificamente, para a questão dos recenseamentos de favelas do Rio de Janeiro. Esses espaços se manifestam, ao menos desde o início do século XX, como um problema político incontornável da cidade. $\bigcirc$ termo favela se consolida no léxico carioca desde a segunda década do século XX e, a partir da promulgação do Código de Obras de 1937, as favelas ganham uma definição jurídica que passa a designar oficialmente espaços específicos da cidade. ${ }^{8}$ No entanto, as favelas ainda não constavam como unidades censitárias específicas, - que dificultava a quantificação dessa realidade na cidade, ao menos até a realização do Censo de favelas do Distrito Federal de 1948.

Censo do Rio de Janeiro de 1906 não faz menção expressa às favelas como unidade censitária específica, mas já compreende algumas áreas, consideradas favelas atualmente, como localidades específicas. Assim, ele faz alusão, por exemplo, ao Morro da Favella $(259$ construções e 2.812 moradores), ao Morro de Santo Antônio (146 construções e 1.844 moradores), 
ao Morro do Pasmado ( 13 construções e 65 moradores), assim como à Praia do Pinto (37 construções e 208 habitantes). ${ }^{9} \bigcirc$ Recenseamento Nacional de 1920 reproduz o mesmo entendimento do censo local de 1906 e já faz menção a outros morros, que se tornarão, posteriormente, conhecidos na cidade, como, por exemplo, os morros Dona Marta (seis construções), de São Carlos (421 construções) ou do Salgueiro (190 construções). ${ }^{10}$

Por sua vez, o Plano Urbanístico do Rio de Janeiro de 1930, elaborado pelo arquiteto francês Alfred Agache, já estipula um conceito para as favelas. Segundo o plano, as favelas eram sinônimos de "barraca provisória", 11 espécies de "cidadessatélites de formação espontânea, que escolheu, de preferência, o alto dos morros, composta, porém, de uma população meio nômade, avessa a toda e qualquer regra de higiene". ${ }^{12}$ Apesar de constatar que a elevação dos morros trazia maior incidência de luz e ar e, por consequência, muitas moradias nas favelas eram mais saudáveis que muitas habitações operárias coletivas, ${ }^{13}$ Agache sugeriria que as favelas eram uma espécie de lepra e deveriam ser substituídas por habitações higiênicas. Estimando, sem explicar sua metodologia de cálculo, em 200 mil moradores nas favelas, afirmava que tais construções eram um impacto para a higiene e para a estética da cidade. ${ }^{14}$

Apesar de consideradas, em grande parte do século XX, como espaços provisórios e precários com vocação a desaparecer, as favelas do Rio de Janeiro cresciam e recebiam cada vez mais moradores. Ora, tornava-se urgente, para os poderes públicos, compreender tais espaços para qualificar melhor sua atuação. O Departamento de Assistência Social da prefeitura do Distrito Federal vinha realizando levantamento de dados de algumas favelas cariocas durante os anos 1940, ${ }^{15}$ mas, como elemento político central para o governo desses espaços e seus residentes, era necessário elaborar um levantamento de maior envergadura do conjunto de favelas da cidade.

presente artigo não busca discutir especificamente os dados quantitativos obtidos pelos recenseamentos, mas, de um lado, analisar a evolução das definições censitárias dos espaços favelados no decorrer dos séculos XX e XXI e, por outro lado, compreender como os serviços nacionais de recenseamento adaptaram suas formas de atuar para levar em consideração as especificidades desses espaços. Em ambos os casos, questionamos como o caso das favelas cariocas se tornou um modelo para pensar os bairros informais no país.

Pretende-se, assim, em primeiro lugar, compreender o contexto político que deu origem ao já mencionado primeiro recenseamento sobre as favelas cariocas, realizado pela prefeitura do Distrito Federal em 1948, e que resultou, dois anos depois, na inserção, pela primeira vez, das favelas como unidade censitária específica no recenseamento nacional decenal de 1950. Será analisada, posteriormente, a evolução
9. Cf. Officina da Estatística (1908).

10. Cf. Directoria Geral de... (1925). A estatística predial do Rio de Janeiro de 1933 tampouco faz alusão às favelas - cf. Departamento de Estatística... (1935). Silva (2005) procurou usar os dados sobre a presença de casebres das distintas circunscrições da cidade para localizar as áreas mais faveladas. No entanto, como indica a própria autora, a presença de casebres em áreas rurais não indica necessariamente a presença de favelas nessas áreas.

11. Agache (1930, p. 380).

12. Ibid., p. 26.

13. Ibid., p. 376 e 380.

14. Ibid., p. 205.

15. O fundo Victor Tavares de Moura do Arquivo da Fiocruz traz algumas fichas de compilação de dados do levantamento realizado em algumas favelas da cidade durante os anos 1940 . 
16. Durante o período imperial (1822-1889), o único órgão com atividades exclusivamente estatísticas era a Diretoria Geral de Estatística, criada em 1871. Com o advento da República, o órgão responsável pelas estatísticas no Brasil mudou de nome e de funções algumas vezes até 1934 , quando foi extinto o Departamento Nacional de Estatística, cujas atribuições passaram aos ministérios competentes. Em 1934, foi criado o Instituto Nacional de Estatística (INE), que iniciou suas atividades em 29 de maio de 1936. No ano seguinte, foi instituído o Conselho Brasileiro de Geografia, incorporado ao INE, que passou a se chamar, então, Instituto Brasileiro de Geografia e Estatística (IBGE). Desde então, o IBGE é responsável em contar a população e identificar e analisar o território. Cf. $<$ https://bit.1y/2OcXNkn> (acesso em: out. 2019).

17. Cf. Silva (2005).

18. Prefeitura do Distrito... (1949, p. 6).

19. Câmara do Distrito Federal, 1948: p. 2290.

20. Correio da Manhã, 19 de fevereiro de 1948. da abordagem dos recenseamentos nacionais sobre os espaços favelados, levantando as expressões utilizadas para designar tais espaços e as questões técnicas envolvidas no tratamento dessas áreas. Por fim, será analisado o último recenseamento de 2010, assim como os questionamentos, que vêm sendo levantados, sobretudo pela Prefeitura do Rio de Janeiro, sobre a pertinência da aplicação da conceituação censitária do Instituto Brasileiro de Geografia e Estatística (IBGE) ${ }^{16}$ para o caso das favelas cariocas.

\section{A FORMAÇÃO DE UM CONCEITO CENSITÁRIO PARA AS FAVELAS}

No conturbado contexto histórico do pós-guerra, o polêmico jornalista e vereador do Rio de Janeiro Carlos Lacerda lançou uma campanha popular denominada "A batalha do Rio de Janeiro", que preconizava a implementação de uma vasta campanha para resolver o problema das favelas da cidade. ${ }^{17}$ Essa campanha propunha a instituição de uma parceria entre os poderes públicos, as diferentes instituições sociais e os indivíduos para resolver o problema das favelas.

Nesse contexto, foi realizado o censo pelo departamento de Geografia e Estatística da Prefeitura do Distrito Federal, entre as últimas semanas de 1947 e as primeiras de 1948. Nesse período, foram identificados os núcleos favelados, organizados os questionários e distribuídos às turmas de recenseadores, que fizeram o trabalho de campo. Foram identificadas pelo censo, inicialmente, 119 favelas com uma população total estimada da ordem de 280 mil habitantes. Esse número foi reduzido para 105 favelas (34.528 casebres e 138.837 pessoas) e tal redução justificada pelo fato de que alguns núcleos favelados estavam situadas em áreas legalizadas, de propriedade de seus moradores, e pela compressão em uma só unidade de núcleos dispostos na mesma unidade topográfica, mas identificados inicialmente com denominações distintas. ${ }^{18}$ Aquele número 1119 favelas, 70.605 casebres e aproximadamente 284 mil pessoas) chegou a ser estranhamente publicado nos anais da Câmara do Distrito Federal, no final de 1948, portanto após os trabalhos de recenseamento, mas ainda antes da publicação final dos dados do censo. ${ }^{19}$

Esses dados iniciais, publicados nos anais da Câmara e posteriormente revistos na versão final do censo, já eram próximos daqueles previstos no início dos trabalhos. Segundo reportagem de O Correio da Manhã, de 19 de fevereiro de 1948, ou seja, ainda durante os trabalhos de recenseamento, uma das recenseadoras afirmou ao jornal que tinham o prazo de 30 dias para recensear todas as favelas e que "lá na repartição temos o mapa com 119 favelas, com seus 70.698 casebres, estando estimada a população em 270.810 almas." 20 
A publicação final do Censo de 1948 faz alusão à previsão inicial, assim como ao receio da época sobre o número excessivo de favelados, sobretudo diante da comoção produzida pela série de artigos da Batalha do Rio de Janeiro. Segundo o censo:
21. Prefeitura do Distrito Federal, Op. Cit., p. 6.

22. Ibid., p. 7.

23. Ibid., p. 6.

Essa estimativa indispensável como base de partida para o censo malgrado se viesse mais tarde verificar ainda exceder muito a realidade já assinalava considerável redução das cifras oscilantes entre 400.000 a 600.000 favelados apresentadas em artigos e reportagens que se multiplicavam na imprensa da cidade. ${ }^{21}$

Apesar de ser notório o esforço do censo para minimizar os números excessivos de favelados na cidade, é difícil afirmar se e como houve ingerência política na metodologia aplicada para reduzir os dados. É provável que os dados publicados nos anais da Câmara fossem ainda as estimativas do censo e não os resultados iniciais. Como não é possível identificar com precisão a natureza desses dados e o censo não nos descreve com detalhes sua metodologia de análise, torna-se difícil concluir a razão técnica dessa drástica diminuição. A explicação do Departamento de Geografia e Estatística dessa diferença se resumiu à "tendência natural em exagerar os dados por parte dos recenseadores":

Decorreu esse decréscimo não só da diminuição do número de favelas, da forma explicada [áreas consideradas legalizadas foram excluídas do censo e a junção de favelas em uma só unidade censitária], como também da tendência natural dos agentes recenseadores em exagerar suas observações sob a impressão das cifras excessivas de divulgação corrente e de natureza atormentada dos terrenos onde a maioria das favelas se acham instaladas. ${ }^{22}$

Os resultados parciais do Censo de 1948 foram regularmente remetidos para a Secretaria Geral do Interior e Segurança em cadernos distintos para cada favela, onde cada um apresentava 24 tabelas precedidas de uma análise dos dados apurados. ${ }^{23}$ Infelizmente, não encontramos arquivos sobre tais trabalhos técnicos realizados no decorrer do censo. Da mesma forma, há um silêncio no documento final sobre os elementos empregados para identificar e classificar uma favela. A justificativa acima mencionada da exclusão de alguns núcleos favelados da contagem final nos leva a concluir que um dos elementos empregados foi provavelmente a natureza jurídica da posse do terreno.

Encontramos alguns dados dos procedimentos metodológicos empregados a partir da descrição do trabalho do Censo nos jornais. As 
24. Correio da Manhã, 19 fev. 1948.

25. Prefeitura do Distrito... op. cit., p. 8.

26. Ibid., p. 11.

27. Anjos (2013, p. 110)

28. Guimarães, op. cit., p. 260.

29. Costa Pinto (1953, p. 134). particularidades urbanísticas das favelas levaram a estratégias específicas de atuação do trabalho censitário nessas áreas. Segundo reportagem de $\bigcirc$ Correio da Manhã, de 19 de fevereiro de 1948, diante da ausência de endereçamento das ruas e casas, os recenseadores pregavam um cartão com as inscrições DGE (Departamento de Geografia e Estatística) nas portas das casas para identificar que o censo já tinha passado por ali. Segundo a mesma reportagem:

E a moça [recenseadora], com sua papelada passou logo em seguida a visitar outro barracão, deixando cartãozinho à porta, bem à vista, para evitar fosse o mesmo barracão visitado duas vezes, talvez por outro recenseador do setor limítrofe, de difícil linha divisória. Nas favelas não há quarteirões, como nas zonas urbanizadas. Não há vestígios, como se sabe, de urbanização em nossos morros. ${ }^{24}$

C Censo de 1948 trouxe, ainda, proposições extremamente racistas, afirmando que pretos e pardos eram "hereditariamente atrasados, desprovidos de ambição e mal ajustados às exigências sociais modernas" 25 e chega a lamentar que as autoridades não levem em consideração medidas eugenistas "suscetíveis de melhorar a raça humana". ${ }^{26}$ Essa posição reproduz o mesmo posicionamento racista e pretensamente científico de censos nacionais anteriores. Apesar do Censo de 1920 não ter pesquisado o quesito racial, em seu texto de introdução é assinalado que o Brasil atingiria a pureza étnica através da miscigenação e da imigração europeia e tal afirmação de branqueamento repete-se na introdução do Censo de 1940.27

Os dados sobre as favelas do Censo nacional de 1950, por sua vez, não reproduz tais afirmações. Alberto Passos Guimarães, analisando o Censo de 1950, pontua de maneira interseccional as condições de trabalho com a questão racial, afirmando que a população de favelas trabalha em atividades de baixa remuneração e que aos grupos preto e pardo "'as atividades de caráter mais elevado' e as 'posições superiores' não são facilmente acessíveis". ${ }^{28}$ Tal posicionamento vai ao encontro do pensamento de Luiz de Aguiar Costa Pinto sobre a segregação racial no Rio de Janeiro, onde "as favelas apresentam-se como núcleos segregados da população pobre e de cor exatamente nos bairros onde os brancos constituem a maioria [...]". 29

A posição racista da "democracia racial", dominante entre as elites culturais e políiticas brasileiras da época, pretende transformar o Brasil em um "laboratório racial", fornecendo o respaldo empírico necessário à crítica, revestida de ciência, da Unesco, contra o horror nazista e os sistemas legais de discriminação racial em países como a África do Sul e os Estados Unidos. Se não há manifestações negativas à presença de "raças" não brancas na composição social da nação a partir do Censo de 1950, observa-se uma pobreza de informações, tanto no 
processo de coleta de dados quanto em sua divulgação, o que, para Edith Piza e Fúlvia Rosemberg, objetivou manter a questão racial no limbo das discussões sobre prioridades nacionais. $\bigcirc$ quesito cor foi inclusive suspenso no Censo de 1970 durante a ditadura militar. ${ }^{30}$ Só a partir do Censo de 1980 que as concepções dominantes sobre a composição racial brasileira foram sendo questionadas por diferentes grupos sociais e integradas gradualmente pelo IBGE. ${ }^{31}$

impacto dos dados do Censo de favelas de $1948^{32}$ fez com que os censos de 1950 e 1960 adotassem algumas informações das fichas do Censo de favelas da prefeitura do Distrito Federal. ${ }^{33}$ Os primeiros censos nacionais de favelas demonstram como questões locais do Rio de Janeiro influenciaram a compreensão de fenômenos nacionais, como, por exemplo, a circulação da categoria "favela" como conceito da geografia urbana própria ao Rio de Janeiro, para pensar a questão dos bairros informais nas cidades brasileiras. ${ }^{34}$

Grande parte do que sabemos do Censo de favelas de 1950 se deve ao já mencionado trabalho de síntese realizado por Alberto Passos Guimarães ${ }^{35}$ e publicado, em 1953, na Revista Brasileira de Estatística. Guimarães esclarece, por exemplo, quando um aglomerado de moradias poderia passar a ser definido como favela. Para ele:

não é sem razão que, no conceito popular, no consenso comum, os núcleos de habitações pobres começam a ser considerados favelas quando se condensam e se comprimem, e que assim não se consideram aqueles núcleos quando ainda esparsos, constituídos embora de casebres do mesmo tipo. ${ }^{36}$

Guimarães se afasta das representações negativas sobre as favelas e seus moradores, próprias das teorias da marginalidade, que monopolizaram o debate sobre esses locais a partir da década de 1950. Ele apresenta uma reflexão mais densa sobre as razões de formação de favelas, identificando que diante das dificuldades crescentes de transporte acessível ou moradia próxima aos locais de trabalho, elas se caracterizariam em soluções de emergência para grande parte da população carioca. Assim, para ele, o movimento demográfico em direção às favelas não é um produto do acaso, mas de causas e fatores que o impeliram num sentido determinado. ${ }^{37}$

Da mesma forma, ele já relaciona "a batalha pela extinção das favelas" às "ambições ocultas de interessados em explorar comercialmente certos terrenos ocupados por núcleos de favelados, suscetíveis de imediata urbanização". ${ }^{38}$ Nesse sentido, o autor afirma que a extinção das favelas estaria circunscrita a uma exigência estética e a um motivo de embelezamento urbano, o que não justificaria
30. Cf. Piza; Rosemberg (1998).

31. Anjos, op. cit., 107.

32. Além do censo da prefeitura, Alberto Passos Guimarães afirma ter tido um levantamento da Fundação Leão XIII nas áreas onde atuava. Não conseguimos ter acesso a dados compilados sobre esse levantamento - Guimarães (1953, p. 256).

33. Oliveira (2014, p. 120).

34. A influência de critérios empreendidos pelo Serviço Nacional de Estatísticas trouxe problemas e necessidades de adaptações, como foi o caso dos censos de favelas de 1955 e $1965 \mathrm{da}$ cidade de Belo Horizonte. As tentativas, por exemplo, de aplicar na capital mineira as proporções mínimas de 50 moradias para se identificar uma favela levou a operações bastante curiosas. Em ambos os censos, reuniram-se favelas vizinhas, para inteirar o número mínimo de moradias, mas apresentavam o resultado, em separado, de cada localidade (Ibid., p. 120).

35. Alberto Passos Guimarães foi um importante militante do PCB. Produziu uma vasta obra sobre economia e a questão agrária e foi funcionário do IBGE.

36. Guimarães (1953, p. 254).

37. Ibid., p. 255. A década de 1950 se apresentará com um processo acelerado de urbanização com importantes fluxos migratórios vindos do Nordeste para as capitais do Sudeste e uma industrialização tardia e dependente. Caberia ao Estado prover dispositivos para impulsionar o desenvolvimento através de um conjunto de métodos e procedimentos para planejar o território, destacando-se justamente o papel do IBGE 
e dos censos nacionais (Bomfim, 2014, p. 1).

38. Guimarães, op. cit., p. 255.

39. O censo de 1950 recenseou 169.305 pessoas nas favelas cariocas. Esse número era bem inferior às previsões elaboradas por órgãos do governo à mesma época, como foi o caso do Serviço Nacional da Febre Amarela, que estipulou, em 1954, que 500 mil pessoas ali residiam - Parisse (1970, p. 31-32).

40. Guimarães (1953, p. 255).

41. Ibid., p. 256.

42. Ibid., p. 256.

43. Ibid., p. 258.

44. Ibid., p. 258

45. Ibid., p. 258. Nesse sentido, o censo acompanhou o entendimento do artigo 349 do código de obras do Distrito Federal de 1937 , cujo conceito de favelas não as limitava somente aos morros da cidade: "A formação de favelas, isto é, de conglomerados de dois ou mais casebres, regularmente disposto ou em desordem construídos por materiais improvisados e em desacordo com as disposições desse decreto, não será absolutamente permitido". Para mais informações sobre o Código de Obras, cf. Gonçalves (2013).

46. Guimarães (1953, p. 258). a remoção de 170 mil pessoas. ${ }^{39}$ Isso implicaria, segundo o autor, a acomodação em áreas distantes de mais de 60 mil famílias, com custos exorbitantes de construção de casas e transporte. ${ }^{40}$ Ainda segundo Guimarães, apesar dos custos de urbanização das favelas, seria mais de acordo com o sentido social e humano da questão. No entanto, ele já levanta, de maneira muito pioneira, a questão que, se depois de urbanizadas as favelas, nelas permaneceriam seus atuais moradores diante da possibilidade de valorização do solo. ${ }^{41}$

Guimarães explica que a ideia do levantamento em separado para as favelas no Censo de 1950 surgiu somente quando já estava iniciada a coleta dos dados e se tinha verificado que a divisão territorial do Distrito Federal, do modo que fora feito pelo Censo, permitiria o conhecimento das características principais dos núcleos localizados na área não urbanizada existente nas imediações do centro da cidade, suscitando, assim, a ideia de trabalhar as favelas como espaços censitários distintos. ${ }^{42}$ Os resultados apresentados, pelo censo, dizem respeito, "apenas, à população presente - que inclui os habitantes presentes em $1^{\circ}$ de julho de 1950, moradores ou não [...] e representam, segundo se estima, $90 \%$ do total dos habitantes das favelas cariocas". ${ }^{43}$

O órgão responsável pela coleta censitária no Distrito Federal considerou como favela os aglomerados que o consenso público classificava como tal, estejam situados nos morros ou em qualquer outra parte. Considerou-se não apenas a configuração do terreno, mas a associação de outros aspectos típicos, dentre os quais o tipo de habitação, a condição de ocupação da área e a ausência de melhoramentos públicos. No entanto, foram excluídos do conjunto os pequenos núcleos de casebres encravados em logradouros públicos. ${ }^{44}$

Com relação à definição de favelas do Censo de 1950, dois aspectos foram levados em conta. Em primeiro lugar, se deveria ficar circunscrita aos morros da cidade. Segundo Guimarães, seria anacrônica tal decisão, já que a "extensão do significado vulgar do termo, atualmente envolvendo grande número de núcleos surgidos ora em lugares planos, ora em terrenos de outra natureza ou até mesmo em arcabouços de edifícios não terminados de construir". ${ }^{45}$ Guimarães afirma, em segundo lugar, que não eram exclusivas das favelas as habitações típicas que nelas predominam, já que esse tipo de construção se observava também em todos os setores da periferia do Rio de Janeiro e em muitos bairros que não poderiam ser tomados, em seu conjunto, por favelas. Isso não excluía, segundo Guimarães, o problema de definir as fronteiras de cada favela e as demais áreas confinantes. ${ }^{46}$ Assim, a suposta precariedade das construções não poderia ser um elemento por si só para definir uma favela, já que muitos bairros periféricos apresentavam tipologias de construção parecidas com as favelas, inclusive as mais centrais. 
Apesar de aumentar o número da população, o número de favelas 47. Ibid., p. 259. diminuiu no Censo de 1950, em relação ao Censo do Distrito Federal de 48. Silva (2009, p. 16). 1948. Uma das razões foi o critério de proporção mínima para definir uma favela e, a outra razão, foi que o Censo nacional considerou com uma só 49. Cavalieri et al. (2016, p. 415).

designação núcleos tomados de forma distinta pela prefeitura do Distrito Federal em 1948, como foi o caso, por exemplo, das favelas de Pavão e Pavãozinho.

Segundo o Censo de 1950, o conceito de favela englobaria os aglomerados humanos que apresentassem total ou parcialmente as seguintes características:

1. Proporções mínimas - agrupamentos prediais ou residenciais formados com unidades de número geralmente superior a 50;

2. Tipo de habitação - predominância, no agrupamento, de casebres ou barracões de aspecto rústico típico, construídos principalmente de folhas de flandres, e napas zincadas, tábuas ou materiais semelhantes;

3. Condição jurídica da ocupação - construções sem licenciamento e sem fiscalização, em terrenos de terceiros ou de propriedade desconhecida;

4. Melhoramentos públicos - ausência, no todo ou em parte, de rede sanitária, luz, telefone e água encanada;

5. Urbanização - área não urbanizada, com falta de arruamento, numeração ou emplacamento. ${ }^{47}$

Se, de um lado, o conceito acima descreve parcialmente a realidade das favelas, por outro lado, consolida a definição das favelas a partir da ausência dos atributos propriamente urbanos para considerar tais espaços como parte integrante da cidade. $\bigcirc$ censo corrobora com à compreensão de Jailson de Souza e Silva, ${ }^{48}$ de que o eixo paradigmático de compreensão das favelas parte do princípio da ausência. A favela é, assim, definida pelo que não seria ou pelo que não teria. Outro elemento peculiar da representação usual das favelas, segundo o mesmo autor, é sua homogeneização. A supervalorização da ausência (de infraestrutura urbana, de arruamento regular, de titularidade, de ordem, de lei, de regras etc.) e a assunção da homogeneidade do fenômeno - como se uma favela representasse todas - fazem, historicamente, com que a diversidade de tipos não seja considerada com a devida ênfase. ${ }^{49}$

Assim, além das proporções mínimas, o censo define as favelas a partir da tipologia das construções, das condições jurídicas precárias tanto em relação ao domínio do solo quanto ao licenciamento urbanístico da construção, a 
50. Guimarães (1953, p. 259).

51. Ibid., p. 259

52. Ibid., p. 259

ausência, no todo ou em parte, de melhoramentos públicos e a urbanização da área, compreendida, aqui, como arruamento, numeração e emplacamento. Parte dessas situações poderia ser encontrada em áreas mais periféricas da cidade e, aliás, algumas zonas foram deliberadamente excluídas por serem pouco numerosas ou integradas no tipo comum de logradouros suburbanos ou rurais, "como, por exemplo, os 237 prédios (casebres) localizados em Guaratiba e os 432 prédios (casebres) localizados na circunscrição das ithas, os quais, em face de melhor exame, ficaram excluídos da classificação de área não urbanizada". ${ }^{50}$

Uma das dificuldades do recenseamento foi a identificação das casas, já que não havia emplacamento das ruas nem numeração das casas pelos quais pudesse se orientar o recenseador. ${ }^{51}$ Isso parece ter sido uma das maiores dificuldades dos primeiros recenseamentos de favelas. Guimarães relata que naquela época era comum os moradores colocarem números inteiramente arbitrários em suas casas, sobretudo com o aproveitamento de placas já usadas em outras construções. Assim, era necessário conciliar os números existentes, embora colocadas ao acaso, com a nova numeração, a que se procurou dar o máximo de continuidade. Algumas casas ainda possuíam numerações inscritas por levantamentos anteriores, como os da Fundação Leão XIII e do Serviço Nacional de Febre Amarela. Tais numerações ainda persistiam em algumas construções, muitas vezes de forma superposta, dificultando a organização do Censo nacional de 1950. Dessa forma, o trabalho foi feito com a organização da numeração das casas e o levantamento topográfico completo de cada favela, à base dos croquis desenhados em cada setor percorrido pelos recenseadores. Alguns desses croquis constam no artigo de Alberto Passos Guimarães. No entanto, segundo Guimarães:

só na [favela da] Praia do Pinto esse trabalho se tornou impraticável, tal a desordem e a dispersão com que foram erguidas as casas, sem qualquer espécie de arruamento. Nesse caso, apenas uma solução foi possível, para que não ficasse sem controle a coleta censitária na Praia do Pinto: a utilização de fotografias aéreas, meio pelo qual a turma especial de recenseadores orientou ali o trabalho. Feito isso, passou-se ao recenseamento do conjunto atacando os setores por todos os lados e ao mesmo tempo. 52

É uma pena que não foi possivel encontrar os originais dos croquis ou as fotos aéreas das favelas recenseadas. De qualquer forma, para Guimarães, o sucesso do censo se deu sobretudo pela ausência de maiores resistências dos moradores, que, ao contrário, cooperaram ativamente com os recenseadores, "a começar pela ajuda prestada no reconhecimento do acidentado terreno, cujos 
desvãos, quase impenetráveis, muito frequentemente passariam desapercebidos a quem não estivesse familiarizado com os caminhos que os servem". ${ }^{53}$

\section{A EVOLUÇÃO DO CONCEITO CENSITÁRIO DE FAVELA}

A conceituação das áreas das favelas no Censo de 1960 obedeceu, exceto no que diz respeito às "proporções mínimas", ao mesmo critério estabelecido para o Censo de 1950. Todavia, dois aspectos concorreram para que o processo de delimitação fosse alterado. Primeiramente, a adoção, para todo o território nacional, do processo de elaboração de cartogramas em substituição aos cadastros prediaisdomiciliares. E, em segundo lugar, o fato de que no decorrer do decênio, tanto as áreas antigas quanto os novos aglomerados surgidos tornaram-se facilmente identificáveis por duas características: denominações específicas e vias de acesso próprias. ${ }^{54}$

Em consequência, os trabalhos de delimitação ficaram restritos à observância das faixas limítrofes das favelas, com a elaboração dos cartogramas, a fim de evitar a interpenetração de áreas de coleta. Constituindo unidades específicas, as áreas das favelas foram recenseadas sob orientação centralizada, através de um grupo especial de recenseadores que contou com a colaboração dos funcionários de diversas instituições, que, naquela época, mantinham unidades de trabalho instaladas nas favelas recenseadas. Enquanto o recenseamento de 1950 abrangeu 58 favelas com o total de 169.305 habitantes, o Censo de 1960 recenseou 147 favelas, com a população total de 335.063 pessoas. ${ }^{55} \mathrm{Em}$ que pese o crescimento da população favelada nessa década, não nos parece que a diferença do número de favelas, entre os dois censos, se explique somente pelo surgimento de novas favelas no período. Tal diferença é provavelmente justificada pela ausência das proporções mínimas como elemento classificador das favelas recenseadas. ${ }^{56}$

Já o recenseamento de 1970 traz novidades sobre a designação dos espaços favelados. ${ }^{57} \bigcirc$ termo favela vem do Rio de Janeiro e é empregado em poucos estados do Brasil. Como mencionamos anteriormente em relação ao Censo de 1950, os censos, tanto de 1950 quanto de 1960, tiveram a tendência de reproduzir questões locais da cidade para a escala nacional. Em 1970, o Rio de Janeiro já não era mais a capital do país e foi, aliás, introduzido uma nova designação para abranger os espaços similares às favelas cariocas. ${ }^{58}$ Segundo o IBGE, os "Aglomerados urbanos excepcionais", geralmente conhecidos como favelas, mocambos, alagados, etc., são os aglomerados urbanos que possuem total ou parcialmente as seguintes características:
53. Ibid., p. 259.

54. $\operatorname{IBGE}(1960$, p. 6).

55. Ibid.

56. Ibid.

57. Segundo Paulo Bomfim (2014, p. 5), observa-se, depois do golpe militar de 1964, certa porosidade do IBGE à ideologia e aos desígnios do regime militar, cujas demandas se tornaram cada vez mais ligadas à estatística e ao fornecimento de dados sobre o território para a execução das políticas governamentais. Aliás, nos anos subsequentes ao golpe, o IBGE se depararia com a presença de verdadeiros interventores militares.

58. As casas de cômodo (cabeças de porco, cortiços, etc.) foram assemelhados a edifícios de apartamentos, considerando-se cada unidade residencial como um domicílio particular - IBGE (1970a, p.15). 
60. Ibid., p. 19.

61. Ibid.

62. IBGE (1983, p. 14). a) Proporções mínimas - agrupamentos prediais ou residenciais formados com unidades de número geralmente superior a 50;

b) Tipo de habitação - predominância, no agrupamento, de casebres ou barracões de aspecto rústico, construídos principalmente de material aproveitado, como folhas de metal, madeira não aparelhada, material de embalagem usado;

c) Condição de ocupação - construções sem licenciamento e sem fiscalização, em terrenos de terceiros ou de propriedade desconhecida;

d) Melhoramentos públicos - ausência, no todo ou em parte, de rede sanitária, luz, telefone e água encanada;

e) Urbanização - área não urbanizada, com falta de arruamento, numeração ou emplacamento. ${ }^{59}$

Apesar do esforço de empregar uma terminologia mais abrangente para a realidade nacional, a definição para os aglomerados urbanos excepcionais reproduzia praticamente o mesmo conceito empregado para as favelas do Censo de 1950. É interessante observar que a descrição dos materiais construtivos das habitações é atualizada. Em vez das "folhas de flandres e napas zincadas" dos censos de 1950 e 1960, o Censo de 1970 descreve os barracos com a utilização principalmente "de folhas de metal, madeira não aparelhada, material de embalagem usado". Esse censo também fez alusão a outras expressões empregadas no país para as favelas, já que afirmava que os aglomerados urbanos excepcionais eram geralmente conhecidos como favelas, mocambos, alagados, etc.

As especificidades urbanísticas dessas áreas também levaram a adaptações metodológicas. $\bigcirc$ censo procurava dividir os setores censitários por quarteirões, numerados em ordem crescente, dentro de cada Setor Censitário, tendo suas faces identificadas por letras alfabéticas, partindo da letra $A$ e prosseguindo no sentido dos ponteiros do relógio. No entanto, antes da divisão por setores censitários de uma localidade, eram primeiramente identificados os Setores Especiais, ou seja, os "Domicílios Coletivos", como os cortiços, e os "Aglomerados Urbanos excepcionais", 60 onde não se aplicava a divisão por quarteirões, tendo em vista as particularidades urbanísticas desses espaços. A população favelada da cidade alcançou, segundo o Censo de 1970, 554.300 residentes. ${ }^{61}$

O Censo de 1980, por sua vez, instituiu os seguintes setores especiais: (i) domicílios coletivos com capacidade de alojamento para mais de 50 pessoas (hotéis, asilos, acampamentos, quartéis, etc.); (ii) aglomerados especiais urbanos (favelas, mocambos, alagados, etc.); e (iii) aldeamentos indígenas. ${ }^{62} \mathrm{O}$ setor especial de aglomerado urbano é aquele aglomerado com no mínimo 50 domić́lios em sua maioria dotados de infraestrutura carente e geralmente localizados em terreno não 
pertencente aos moradores. Tais concentrações domiciliárias, como é o caso das favelas, mocambos, palafitas, etc., foram também cuidadosamente localizadas no Mapa Urbano para fins estatísticos (MUE) e isoladas como setores especiais de aglomerados urbanos, visando posterior tratamento dos dados coletados. ${ }^{63}$

- conceito empregado pelo Censo de 1980 se difere dos censos anteriores. Segundo Valeria Costa Grace, a partir de 1980, as definições das áreas de favela já dão um peso menor à falta de equipamento urbano básico, ao admitir-se em alguns casos a sua existência, mesmo que de forma precária ou parcial. Da mesma forma, os aspectos materiais construtivos das residências também deixam de ser, pouco a pouco, considerados como elementos diferenciadores deste espaço, e são doravante excluídos da definição. Isso reflete provavelmente o progressivo aumento das construções em alvenaria nas favelas. As definições das áreas faveladas vão se voltar mais para a descrição do espaço do que das unidades habitacionais. No entanto, a definição continua destacando o aspecto da "desordem" e da falta de arruamento. ${ }^{64}$

De qualquer forma, ao limitar o número de moradias e o aspecto da construção, a definição, além de ficar imprecisa e subjetiva, não considerou a evolução da favela até então. Isso demonstra que os conceitos e preconceitos relativos à favela, interiorizados por todos, são muito influenciados pelo senso comum, dificultando a absorção das transformações ocorridas para a formalização de um conceito de base técnico-científica operacional mais condizente com a realidade. ${ }^{65}$ Muitos dos conceitos já datavam de 30 anos e que a diferenciação desses espaços começava a ser cada vez maior, trazendo prejuízos ao conceito estabelecido. ${ }^{66}$

Nesse contexto, a prefeitura do Rio de Janeiro, em dezembro de 1982, empreendeu um cadastro de favelas, baseado em levantamento aerofotográfico de 1975, em trabalho de campo realizado no mesmo ano de 1982 e em informações da concessionária de energia, das associações de moradores e de outros dados secundários. Apesar de não ser um trabalho propriamente censitário, os dados surpreenderam, já que o Censo de 1980 tinha aferido 191 favelas, enquanto a Empresa Municipal de Informática do Rio de Janeiro (lplanrio) anunciou a existência de 377.67 Além da diferença temporal, já que os dados da Iplanrio foram computados dois anos depois do censo do IBGE, o que explica tal diferença parece ser a utilização de metodologias distintas, já que a Iplanrio não estipulou proporções mínimas (50 unidades) para classificar uma favela e não juntou favelas em uma só unidade, como foi feito pelo Censo de 1980 do IBGE. ${ }^{68}$

Os resultados diferenciados entre os dados do Censo de 1980 e da Prefeitura do Rio de Janeiro são consequência da utilização de conceitos e metodologias diferenciadas entre as duas fontes. A Iplanrio, ao delimitar o
63. IBGE (1981, p. 7).

64. Costa (1996, p. 29).

65. Ibid., p. 30.

66. Oliveira; Niemeyer (1983, p. 4).

67. Ibid., p. 5.

68. A Prefeitura do Rio de Janeiro possui um Sistema de Assentamentos de Baixa Renda (Sabren), que foi criado em 1990 e tem origem justamente nesse $\mathrm{Ca}$ dastro de Favelas da Cidade do Rio de Janeiro de 1982. O Sabren reúne e divulga informações sobre as favelas e loteamentos irregulares e clandestinos e é, atualmente, gerenciado pela Diretoria de Informações da Cidade do Instituto Pereira Passos (IPP) -Cavalieri et al. (2016, p. 414). 
69. Costa (1996, p. 31).

70. Oliveira; Niemeyer (1983, p. 17-18)

71. Em um contexto de corte do funcionalismo público do governo Fernando Collor de Mello (1989-1992), houve um atraso na contratação dos recenseadores, o que não permitiu que o censo se realizasse ainda em 1990.

72. A prefeitura do Rio de Janeiro manteve a designação favela e utilizava o conceito descrito no artigo 147 do Plano Diretor de 1992 (lei complementar $\mathrm{n}^{\circ} 16$ de 4 de junho de 1992): "Para fins de aplicação do Plano Diretor Decenal, favela é a área predominantemente habitacional, caracterizada por ocupação da terra por população de baixa renda, precariedade da infra-estrutura urbana e de serviços públicos, vias estreitas e de alinhamento irregular, lotes de forma e tamanho irregular e construções não licenciadas, em desconformidade com os padrões legais."

73. IBGE (1991, p. 110).

74. Ibid.

75. Ferreira et al. (2007, p. 3). espaço da favela, considerou, como elementos definidores principais, as características de invasão na época de sua ocupação e a falta do título de propriedade da terra. Ao contrário do Censo de 1980, não limitou o número mínimo de domicílios nem considerou a estrutura física destes, resultando na inclusão dos domicílios que apresentaram certa infraestrutura e benfeitorias. ${ }^{69}$

A discussão suscitada pelos dados da Iplanrio levantou a necessidade de uma reflexão sobre os conceitos utilizados pelo IBGE de forma que fossem menos centrados na descrição física homogeneizante desses espaços e mais sobre a propriedade da terra. No entanto, esse quesito traz dificuldades quanto ao levantamento no censo, diante da resistência dos moradores de relatar tais características e dos custos de realizar uma pesquisa fundiária mais aprofundada nas favelas no contexto dos trabalhos censitários. ${ }^{70}$

Mais novidades sobre a nomenclatura e classificação de favelas vieram no Censo de 1991. ${ }^{71}$ Foi introduzida a infeliz designação de aglomerados subnormais para designar favelas e assemelhados e que, por sinal, se mantém até os dias atuais. ${ }^{72}$ Considerou-se aglomerado subnormal todo conjunto constituído por unidades habitacionais (barracos, casas, etc.) ocupando ou tendo ocupado, até período recente, terrenos de propriedade alheia (pública ou particular) dispostos, em geral, de forma desordenada e densa, e carentes, em sua maioria, de serviços públicos essenciais. $\bigcirc$ que caracteriza, por fim, um aglomerado subnormal é a ocupação desordenada e que quando da sua implantação não houvesse posse da terra ou título de propriedade. $O$ censo ainda define como casa ou apartamento em aglomerado subnormal todo domićlio que fizesse parte de um conjunto subnormal, também designado '"assentamento informal", como, por exemplo: favela, mocambo, alagado, barraco de rio, etc. ${ }^{73}$ Segundo o Censo de 1991, a população favelada da cidade do Rio de Janeiro atingiu 882.483 residentes. ${ }^{74}$

Há um esforço de relativizar certas características para definir os aglomerados subnormais, já que, de um lado, como mencionamos anteriormente, questões sobre a precariedade do material das moradias não seria mais pertinente, haja vista a disseminação de construções em alvenaria nas favelas. Os projetos de urbanização de favelas, a partir dos anos 1980, trouxeram maior segurança da posse aos moradores e, por conseguinte, maior investimento dos moradores em suas casas e melhoria generalizada das construções. Relativizar esse aspecto era um esforço do censo para absorver a heterogeneidade da configuração dos espaços favelados.

Por outro lado, questões relacionadas com a propriedade são difíceis de verificar no censo, já que é comum os moradores de favelas se declararem proprietários, sem maiores objeções sobre a existência ou não de um título registrado de propriedade. ${ }^{75}$ Para a Região Metropolitana do Rio de Janeiro, 
entretanto, tanto nos setores de favela como nos não favela surgiu a categoria "só a construção própria". 76 Entre as casas de favela, onde se esperava que todas as unidades tivessem propriedade da terra irregular, computaram-se 86 mil moradias com terreno próprio. E, entre as unidades "não favela", surgiram quase 150 mil que declararam apenas a construção própria (cerca de 9\% do estoque total de moradias). ${ }^{77} \bigcirc$ que fica claro é que a centralidade do critério da titularidade do solo para definir as favelas é extremamente problemática.

No que se refere ao processo de delimitação e adoção de uma base cartográfica operacional para a pesquisa em favelas, também ocorreram modificações no decorrer do período. Em 1950, como citamos acima, considerou-se os cadastros prediais domiciliares. Já em 1960, houve elaboração de cartogramas, que consistiram no cadastro preliminar das favelas a serem recenseadas, tendo como base as informações de outros órgãos de atuação mais específica em favelas. No Censo de 1970, os aglomerados especiais urbanos foram inseridos no Mapa Urbano para fins estatísticos (MUE) e, em 1980, os limites das favelas em relação aos censos anteriores foram atualizados e revisados em campo pelo pesquisador na ocasião do recenseamento. Em 1991, por sua vez, os setores foram novamente delimitados e atualizados por ocasião da preparação de uma base Operacional Geográfica do Censo. ${ }^{78}$

C Censo de 2000, por fim, manteve a mesma designação e conceituou o Setor Especial de Aglomerado Subnormal como o conjunto constituído por no mínimo 51 domicílios, ocupando ou tendo ocupado até período recente terreno de propriedade alheia - pública ou particular -, dispostos, em geral, de forma desordenada e densa e carentes, em sua maioria, de serviços públicos essenciais. Podem se enquadrar, observados os critérios de padrões de urbanização e/ou de precariedade de serviços públicos essenciais, nas seguintes categorias: i) invasão; ii) loteamento irregular ou clandestino; e iii) áreas invadidas e loteamentos irregulares ou clandestinos regularizados em período recente. ${ }^{79}$ Os setores especiais de aglomerados subnormais são, por sua vez, divididos em setores censitários com no mínimo 51 e no máximo 350 domicílios, ou seja, a mesma favela pode ser formada por mais do que um setor censitário. ${ }^{80} \mathrm{~A}$ população favelada da cidade alcançou 1.092 .958 em 2000.81

A pergunta sobre a forma de construção acabou sendo retirada dos questionários dos censos. ${ }^{82}$ Da mesma forma, afirmam que questões relacionadas com a condição da propriedade tampouco auxiliavam, uma vez que os moradores de favelas, como mencionamos acima, se declaram proprietários, sendo difícil a identificação da natureza dos títulos fundiários porventura existentes. Outra dificuldade identificada pelo Censo de 2000, no trabalho dos recenseadores, foi a caracterização nas Folhas de Coleta dos setores de situação rural e de
76. Cf. Taschner (2000).

77. Ibid., p. 6.

78. Costa (1996, p. 32).

79. IBGE (2003, p. 229).

80. Ibid., p. 279.

81. Ibid.

82. Marques et al. (2007, p. 13). 
83. IBGE (2003, p. 182)

84. Ibid., p. 227.

85. Ibid., p. 227

86. Ibid., p. 227

87. A diferença da mensuração da população favelada sempre foi um grande problema. Parisse (1970, p.3132) levantou estimativas da população favelada por diversos órgãos públicos nas décadas de 1950 e 1960 e os comparou com os dados censitários. Em alguns casos, essas estimativas eram quase $300 \%$ superior aos dados dos censos nacionais.

88. Guerreiro cita os casos dos censos realizados pelos moradores nas favelas do Fallet, da Rocinha e do Vidigal com dados muito distintos daqueles do censo oficial. Guerreiro (2019, p. 120) reforça que esses recenseamentos não apresentaram a metodologia aplicada e era difícil verificar a pertinência dos dados apresentados. aglomerado subnormal. Esse fato, segundo o IBGE, pode estar associado, nessas áreas, à maior irregularidade no traçado dos logradouros e à falta de quarteirões. Assim, a identificação desses setores envolveu maior subjetividade e, portanto, maior dificuldade para caracterização. Isso pode ser atribuído, segundo o IBGE, à falta de intervenção pública nesses espaços, ao padrão irregular do traçado dos logradouros, assim como à extensão dos logradouros nos setores rurais. ${ }^{83}$

Para o Censo Demográfico de 2000, foram elaborados e incluídos na Caderneta do Setor e na Folha de Coleta quesitos referentes à caracterização do entorno dos domicílios, os quais estão associados à existência de iluminação pública, identificação e pavimentação/calçamento nos logradouros. Esses quesitos foram elaborados com o objetivo de atender à demanda de usuários, dentre eles tendo destaque os órgãos municipais de planejamento urbano, já que tais perguntas constituem informações de grande importância para o estudo e para a definição de políticas públicas. ${ }^{84}$

Isso demonstra a importância dos dados do censo no governo das cidades, sobretudo diante do fato que muitos projetos de urbanização de favelas se iniciaram na década de 1980 sem dados suficientes para subsidiar tais intervenções. A elaboração dos quesitos teve como objetivo, segundo o IBGE, constituir o elenco de indicadores que seriam utilizados para "identificar as áreas com características de exclusão da cidade formal, como os aglomerados subnormais - favelas e áreas assemelhadas". ${ }^{85} \bigcirc$ procedimento metodológico para definição dos quesitos correspondeu aos seguintes passos: levantamento bibliográfico realizado pelos técnicos da Diretoria de Geociências e Diretoria de Pesquisas e reuniões entre técnicos dessas diretorias, para avaliação das características fundamentais, levantadas na literatura, que poderiam compor os quesitos para caracterização do entorno dos domicílios. Foram considerados aqueles aspectos associados à falta de acesso aos serviços públicos essenciais, como infraestrutura urbana. Dessa forma, aspectos como o traçado tortuoso e a limpeza das ruas, envolvendo varredura, também foram arrolados em um primeiro momento. ${ }^{86}$

Os dados formulados pelos censos sempre sofreram forte crítica pelo fato de não descreverem a realidade das favelas. ${ }^{87}$ Foram realizadas experiências locais de mapeamentos e recenseamento de populações e atividades locais. ${ }^{88} \mathrm{O}$ censo realizado no complexo de favelas da Maré em 2000, por exemplo, foi uma parceria entre o Centro de Estudos e Ações Solidárias da Maré (Ceasm), com recurso do Banco Nacional de Desenvolvimento Econômico e Social (BNDES), e apoio técnico do Instituto de Pesquisa Econômica Aplicada (lpea) e da Escola Nacional de Ciências Estatísticas (Ence) e subsidiado com dados do IPP. O objetivo era construir uma percepção mais fiel da realidade para melhor subvencionar com dados as políticas públicas locais e 
permitir o aproveitamento dos moradores como pesquisadores, já que muitos estavam começando a acessar as universidades. ${ }^{89}$ Segundo Eugenia Motta, produzir seus próprios números, para os organizadores do censo local, seria disputar a forma pela qual a favela é percebida publicamente e tratada pelos agentes estatais. ${ }^{90}$

censo trouxe uma crítica ao paradigma da ausência para definir as favelas, assim como a perspectiva homogeneizadora desses espaços. Segundo o censo da Maré, "a percepção anacrônica dos espaços populares ampliou o seu alcance, de forma que as ocupações continuaram a ser percebidas como um espaço de ausências urbanas, sociais, legais e morais". ${ }^{91}$ Esse censo procurou trabalhar com os sub-bairros locais, definindo os setores censitários a partir da divisão menor em quarteirões. Isso não foi uma iniciativa complicada na Maré, já que muitas áreas dali são oriundas de projetos públicos de construção de habitação social, sendo relativamente simples a identificação de ruas e quadras.

Da mesma forma, o censo da Maré formulou duras críticas aos trabalhos censitários realizados previamente pelo IBGE na Maré e em outras favelas. Em primeiro lugar, houve o acompanhamento do trabalho de campo com a correlação dos códigos identificadores que vinculam os questionários aos mapas préatualizados. Isso permitiu um mapeamento prévio e mais seguro, evitando que certas zonas fossem "esquecidas" pelo censo. Em segundo lugar, a forma de remuneração dos recenseadores, ao contrário do IBGE, era fixa e não por questionário. Assim, alguns recenseadores tiveram que ir mais de cinco vezes à mesma casa para conseguir a informação de uma só família. Não havia o risco de eles abandonarem certos setores diante da redução da remuneração pelo preenchimento de número pequeno de questionários em determinado momento. Para o censo da Maré, o complexo de favelas possuía, em 2000, 132.176 habitantes, divididos em 38.273 domicílios, enquanto para o censo do IBGE do mesmo ano a população da Maré seria somente de 113.817 .92

Foi realizado outro censo da Maré, nos anos 2012 e 2013, pela organização Redes da Maré. Contou com o auxílio do Instituto Pereira Passos (IPP), que cedeu a base cartográfica digital (em arquivos de dados geoespaciais denominados shapefiles). De posse dos croquis dos setores e da descrição de seus perímetros, uma grande equipe de pesquisadores, todos moradores da Maré, percorreu cada um dos mais de 800 logradouros, ruas, becos, travessas, praças etc. A participação de moradores e lideranças de todos as favelas do complexo da Maré foi extremamente importante para cobrir toda a área. $\bigcirc$ Censo de 2010 do IBGE contou 135.989 moradores em toda a Maré, incluindo a favela de Marcílio Dias. Já o Censo local da Maré contou 139.073
89. Ceasm (2003, p. 31).

90. Motta (2019, p. 75).

91. Ceasm (2003, p. 25-26).

92. Ibid., p. 35-38. 
93. Redes da Maré (2019, p. 18).

94. IBGE (2009, p. 2).

95. Ibid., p. 19.

96. Ibid., p. 3 . moradores, ou seja, somente 3.084 a mais, o que confere grande proximidade entre ambos, resultado distinto do censo mencionado anteriormente da Maré. ${ }^{93}$

\section{O CENSO DE 2010 E O DEBATE ATUAL SOBRE O CONCEITO CENSITÁRIO DE FAVELAS}

O conceito elaborado e apresentado pelo Manual de Referências Técnicas para a elaboração da Base Territorial para o Censo Demográfico de 2010 define os aglomerados subnormais como "um conjunto constituído de, no mínimo, 51 unidades habitacionais (barracos, casas...) carentes, em sua maioria de serviços públicos essenciais, ocupando ou tendo ocupado, até período recente, terreno de propriedade alheia (pública ou particular) e estando dispostas, em geral, de forma desordenada e densa". 94 Ainda segundo o mesmo documento, os aglomerados subnormais podem ser identificados nas áreas urbanas e nos aglomerados rurais do tipo extensão urbana. $\bigcirc$ documento é mais preciso para a identificação desses aglomerados, que deve ser feita com base nos seguintes critérios:

a) Ocupação ilegal da terra, ou seja, construção em terrenos de propriedade alheia (pública ou particular) no momento atual ou em período recente (obtenção do título de propriedade do terreno há dez anos ou menos); e b) Possuírem ao menos uma das seguintes características: i) urbanização fora dos padrões vigentes - refletindo por vias de circulação estreitas e de alinhamento irregular, lotes de tamanhos e formas desiguais e construções não realizadas por órgãos públicos; e ii) precariedade de serviços públicos essenciais. ${ }^{95}$

Dessa forma, as referências básicas para o Censo de 2010 identificavam que os aglomerados subnormais podem se enquadrar, observados os critérios de padrões de urbanização e/ou de precariedade de serviços públicos essenciais, nas seguintes categorias: a) invasão; b) loteamento irregular ou clandestino; e c) áreas invadidas e loteamentos irregulares e clandestinos regularizados em período recente. Há algumas particularidades na ficha do Censo de 2010, como a previsão de informações, por parte dos recenseadores, sobre a segurança de acesso, o que já demonstra uma maior preocupação diante do aumento da presença do controle dessas áreas por grupos armados. Da mesma forma, há a previsão de questionar os moradores para que eles informem de como denominam o local onde vivem (favela, mocambo, grota, vila, etc.1.96 Apesar de ter mantido a expressão aglomerados subnormais, observa-se um esforço de superar a generalização de um termo específico para designar os bairros considerados informais no país. 
Como já mencionamos em relação à iniciativa do censo da Maré, uma das questões levantadas sobre a pertinência dos dados produzidos pelo IBGE é o fato de que muitos domicílios não são efetivamente recenseados, seja por falta de pessoal, seja pela dificuldade de acesso, por questões muitas vezes de segurança, a certos setores classificados como aglomerados subnormais. Segundo o IBGE, a classificação de um domicílio na categoria de fechado, ou seja, não recenseado, mas identificado, é equivalente a considerá-lo como uma não resposta, que é um dos erros não amostrais mais comuns na realização de uma pesquisa, seja ela censitária ou por amostragem. ${ }^{97}$

Ainda segundo o IBGE, uma das formas de lidar com uma não resposta é a que utiliza procedimentos de imputação, ou seja, atribuir informações individuais às unidades sem informação, de forma que a perda de dados seja aleatória. Busca-se, assim, estabelecer um padrão de não resposta conhecido ou pelo menos estimado, para ser considerado durante o tratamento da não resposta por imputação. Para estimar as características dos domicílios fechados e de seus moradores para cada município abrangido pelo Censo Demográfico 2010, definiuse cada domicílio fechado como uma não resposta, cujo atributo necessário é o número de moradores e demais características. $\bigcirc$ tratamento adotado para essa não resposta foi um procedimento de imputação por meio de seleção aleatória de um domicílio doador entre um conjunto de possíveis doadores, tendo sido adotada, ainda, a estratificação de domicílios acima descrita. ${ }^{98}$

É difícil identificar, no atual trabalho, como tal imputação pode efetivamente corrigir possíveis desvios de dados. Seria necessário acessar dados internos do censo para identificar onde e com que frequência essa imputação acontece. ${ }^{99}$ No entanto, escutamos com frequência dos moradores de favelas que nunca foram entrevistados pelos censos. É bem provável que os dados sobre as favelas cariocas sejam subestimados e que muitas moradias nem sequer tenham sido contabilizadas como domicílios fechados, o que as impediu de serem tratadas como uma não resposta. Essa questão traz impactos importantes que ultrapassam, por sinal, o debate sobre as favelas, já que podem alterar o cálculo da população total da cidade. Isso influenciaria, por exemplo, no cálculo de repasses ao Rio de Janeiro do fundo de participação dos municípios, e cujos valores são distribuídos de acordo com o número de habitantes de cada município determinado pelo IBGE.

Outro elemento importante do Censo de 2010 foi o esforço em identificar as fronteiras dos aglomerados subnormais. Segundo o IBGE, áreas como a favela da Rocinha apresentam fortes contrastes com bairros vizinhos urbanizados dentro de padrões regulares e são, assim, facilmente perceptíveis. No entanto, ainda segundo - IBGE, em outras áreas tais limites são difusos e de difícil identificação. $\bigcirc$ censo de 2010 introduziu, assim, o trabalho com imagens de satélite de alta resolução, o que
97. IBGE (2010, p. 24)

98. Ibid., p. 24 .

99. Segundo o IBGE (2010, p. 25), o procedimento de estimação foi aplicado aos domicílios efetivamente fechados, após todas as tentativas de obtenção da entrevista, que correspondem a 1,3\% do total de domicílios particulares abrangidos pelo Censo Demográfico 2010. A população total estimada por esse procedimento é de 2.795 .533 pessoas, em 899.152 domicílios fechados. Essa porcentagem parece realmente irrisória para trazer desvios importantes nos dados finais do censo. No entanto, a documento do IBGE não faz alusão sobre a porcentagem de domicílios fechados em aglomerados subnormais e, mais especificamente, na cidade do Rio de Janeiro. 
100. Ibid., p. 27.

101. Ibid., p. 27.

102. IBGE (2016, p. 365).

103. Mation et al. (2014, p. 13). representou uma mudança qualitativa para a identificação das áreas em relação aos censos passados. As imagens foram utilizadas para encontrar partes dos municípios que possuíssem morfologia característica de aglomerados subnormais e que seriam, posteriormente, investigadas em campo para a confirmação das características. ${ }^{100}$

Outra inovação no tratamento do tema, segundo o IBGE, foi a realização de pesquisa específica - Levantamento de Informações Territoriais (LT) - com o objetivo de melhorar a identificação e a caracterização dos aglomerados subnormais, composta por um módulo de campo (LIT-Campo) e outro módulo de investigação junto às prefeituras (LTT-Prefeitura). Tanto a observação de campo quanto o trabalho junto às prefeituras permitiram uma melhor identificação dos padrões urbanísticos e da situação fundiária e legal dos possíveis aglomerados subnormais, contribuindo, finalmente, para a atualização dos cadastros e mapas censitários. ${ }^{101}$

Segundo o IBGE, há uma grande diversidade de tipos e tamanhos de aglomerados subnormais. O conceito empregado pelo IBGE apresenta um grau de generalização para abarcar a diversidade de assentamentos irregulares existentes no país, distanciando, assim, das definições dos primeiros censos, mais próximas à realidade das favelas cariocas. Para melhorar os padrões de qualidade na identificação dos aglomerados subnormais, o IBGE introduziu inovações gerenciais, metodológicas e tecnológicas, com destaque, como já mencionado, do uso de imagens de satélite de alta resolução, e o desenvolvimento e aplicação do Levantamento de Informações Territoriais, além da realização de reuniões sobre o tema nas Comissões Municipais de Geografia e Estatística. ${ }^{102}$ Isso permitiu, inclusive, que mais informações fundiárias estivessem previamente disponíveis às equipes do IBGE. ${ }^{103}$

Segundo manifestação do então presidente do IBGE Eduardo Pereira Nunes ao jornal $\bigcirc$ Globo de 5 de junho de 2011 , a identificação e a delimitação dos aglomerados subnormais foram aperfeiçoados graças ao uso generalizado de imagens de satélite. Ele descreve o trabalho em três fases: 1) identificação e delimitação da mancha por imagens de satélite; 2) levantamento de informações territoriais; 3) visitas das casas e avaliação das condições do entorno (saneamento básico, iluminação pública, qualidade do arruamento, etc.). A partir dessa análise dos formulários, é decidido se se trata ou não de um grupamento subnormal.

Os censos vinham sofrendo críticas quanto à caracterização dos aglomerados subnormais. Costa e Nascimento afirmaram, em 2005, que as intervenções urbanísticas descaracterizam, para o censo, muitas vezes as áreas como "favelas", sobretudo no que se refere às características de infraestrutura, mudando substancialmente a paisagem, embora a maior parte delas ainda permaneça com situação irregular no que se refere à propriedade. Diante das dificuldades jurídicas 
para a regularização dessas áreas, que não acompanham os projetos de urbanização realizados, a questão da posse da terra deixa de ter um grande significado e passa, segundo os autores, a ser um entrave à definição de favelas e assemelhados pelas prefeituras. Muitas áreas urbanizadas acabam mantendo essa definição, mesmo após a realização de programas de urbanização, como foi o caso do programa Favela-Bairro, desenvolvido pela prefeitura do Rio de Janeiro. ${ }^{104}$

Como já mencionamos, a prefeitura vem desenvolvendo trabalhos de levantamento censitário das favelas desde a década de 1980. A definição utilizada atualmente pela prefeitura para favela é a constante do Plano Diretor do Rio de Janeiro de 2011 , a saber: "área predominantemente habitacional, caracterizada por ocupação clandestina e de baixa renda, precariedade da infraestrutura urbana e de serviços públicos, vias estreitas e alinhamento irregular, ausência de parcelamento formal e vínculos de propriedade e construções não licenciadas, em desacordo com os padrões legais vigentes". ${ }^{105}$ As características que o Instituto Pereira Passos (IPP) considera para definir uma área como favela são: 1) ocupação irregular da terra; 2) falta de títulos de propriedade formais, o que não significa que a ocupação seja ilegal; 3) tecido urbano disposto de forma irregular; 4) lotes pequenos e indefinidos; 5) vias estreitas; 6) infraestrutura de saneamento precária; 7) equipamentos sociais inexistentes ou insuficientes; 8) habitações precárias em desacordo com as normas; 9) inexistência ou precariedade de normas urbanísticas especiais; 10) não inserção dos imóveis nos cadastros imobiliários; 11 ) predominância de população de baixa renda. ${ }^{106}$

Segundo Cavalieri e Vial, não há maiores problemas para identificar as favelas antigas. Entretanto, à medida que o tempo vai passando, as formas mistas vão surgindo com mais intensidade e fica cada vez mais difícil diferenciar, por exemplo, situações típicas de um loteamento clandestino e de uma favela. As tipologias se misturam e fica complicado identificar a questão do título da propriedade. Há situações, por exemplo, nos casos de projetos de urbanização em que o poder público prefere tratar o loteamento como se fosse uma favela. ${ }^{107}$

Apesar da compatibilização dos limites e nomenclaturas de favela entre IBGE e Instituto Pereira Passos (IPP), ainda persistem algumas diferenças, embora muito mais reduzidas que no passado. No ano 2000, aproximadamente $11 \%$ dos limites eram incompatíveis, percentual reduzido para cerca de 3,5\% em 2010. ${ }^{108}$ Apesar do esforço de aproximar os dados do IPP e do IBGE, persistem ainda algumas diferenças, sobretudo pelo fato de que o IBGE ainda mantém um número mínimo de 51 domicílios para considerar um conjunto como aglomerado subnormal. Assim, algumas poucas áreas apontadas como favelas pelo IPP não foram assim consideradas pelo IBGE. Dessa forma, o IPP, usando
104. Costa; Nascimento (2005, p. 3083).

105. Cf. Rio de Janeiro (2011).

106. Cavalieri; Vial (2012a, p. 6).

107. Ibid., p. 4.

108. Ibid., p. 3 . 
109. Ibid., p. 6.

110. O programa Morar Carioca foi anunciado pela prefeitura em 2011 e pretendia urbanizar o conjunto de favelas da cidade. Algumas equipes chegaram a ser contratadas e realizaram estudos prévios às intervenções, mas o programa foi rapidamente esvaziado pela prefeitura. Sobre o Morar Carioca, cf. Cavalcanti (2017).

111. Ibid., p. 4. suas bases cartográficas e aerofotogramétricas, fez algumas estimativas para complementar os dados, o que, ao fim e ao cabo, resultou num acréscimo de aproximadamente 3,5\% sobre a população calculada pelo IBGE. Para o IPP, a população favelada na cidade iá alcançava 1.443.773 moradores, enquanto para o Censo de 2010 eram 1.393.314 habitantes. ${ }^{109}$

A reflexão em torno do conceito de favelas levou a um questionamento da própria pertinência de continuar nomeando lugares como favelas, o que se manifestou na nova classificação elaborada pelo programa municipal de urbanização de favelas Morar Carioca. ${ }^{10}$ Segundo Cavalieri e Vial, a preocupação da prefeitura era classificar a enorme quantidade de favelas existentes no município para planejar uma política pública mais coerente e integrada. A ideia era levar em consideração a heterogeneidade desses espaços. Os três grandes eixos de classificação de favelas foram situação no tecido urbano, tamanho e grau de urbanização. ${ }^{111}$

Quanto à situação no tecido urbano, as favelas foram classificadas como isoladas ou em complexos. As isoladas eram as que apresentavam limites claramente identificáveis, com denominação própria e distante de outros assentamentos. Os complexos eram formados por favelas que, por sua proximidade, conformavam uma mancha urbana única ou guardavam fortes relações entre si. Essa junção de favelas suscitou inúmeras críticas, já que muitas vezes favelas com fortes rivalidades, normalmente suscitadas pelo controle territorial desses locais por grupos armados rivais, acabaram sendo incorporadas, a contragosto, em complexos de favelas mais amplos. Quanto ao tamanho, as favelas foram classificadas em: 1) pequenas, até cem domicílios; 2) médias, de cem a quinhentos domicílios; 3) grandes, acima de quinhentos domicílios.

No entanto, o que mais gerou questionamentos foi o grau de urbanização. As favelas foram classificadas em: 1) em análise; 2) parcialmente urbanizada; 3) urbanizável; 4) em processo de urbanização; e 5l urbanizada. Os assentamentos "em análise" referem-se àqueles cuja possibilidade de urbanização, total ou parcial, deve ser verificada através da realização de estudos e dimensionamentos para a elaboração de laudos técnicos, levando-se em conta situações de risco e inadequação para o uso residencial. A partir daí, podem ser, total ou parcialmente, enquadrados como urbanizável e/ou ter seus moradores reassentados. "Parcialmente urbanizada" é a classificação dada àquele assentamento que foi objeto de programas de urbanização integrada, mas que ainda requer a complementação e/ou recuperação da infraestrutura, ampliação da acessibilidade, tratamento adequado de áreas de risco e iniciativas de desadensamento parcial da favela. "Urbanizável" refere-se ao assentamento que não foi objeto de programas de urbanização integrada e pode ser 
consolidado na malha urbana formal da cidade. "Urbanizada" corresponde ao assentamento que tenha sido objeto de programas de urbanização integrada, cujo projeto tenha garantido a implantação de infraestrutura básica, equipamentos públicos e níveis de acessibilidade satisfatórios, ou que, por esforço próprio de seus moradores e ações públicas diversas, ao longo do tempo, conseguiu alcançar uma situação satisfatória de urbanização. ${ }^{112}$

Dos 1.443.773 moradores de favelas, 283.058 moravam em áreas denominadas como comunidades urbanizadas. Segundo o jornal $\bigcirc$ Globo de 5 de junho de 2011,44 favelas passaram a ser chamadas de comunidades urbanizadas. Os jornais rapidamente identificarem essa nova denominação como ex-favelas. Em que pese o fato de que a prefeitura nunca usou esse termo, essa nova nomenclatura foi objeto de críticas de moradores e urbanistas. ${ }^{113} \bigcirc$ presidente do IPP à época, Ricardo Henriques, justificou essa nova nomenclatura em entrevista ao jornal $\bigcirc$ Globo do dia 29 de maio de 2011 da seguinte forma: "O que nós queremos é promover uma reflexão sobre o conceito de favela. $\bigcirc$ caso da [favela da] Providência (no Centro) é bem ilustrativo. Ela será reurbanizada e daqui a pouco não haverá sentido de classificá-la assim. E isso sem prejuízo da história, da tradição e da identidade da Providência (considerada a primeira favela do Brasil)." O objetivo dessa nova denominação era demarcar a heterogeneidade dos espaços favelados, permitindo uma melhor qualificação da intervenção dos poderes públicos nesses espaços. No entanto, essa nova denominação trouxe, indiretamente, uma reflexão mais ampla sobre o próprio conceito de favela e a pertinência ou não que um espaço possa, um dia, parar de ser assim definido.

\section{CONCLUSÃO}

presente artigo procurou levantar a evolução do conceito censitário de favelas desde o Censo do Distrito Federal de 1948 até o último Censo nacional de 2010. Se o mencionado censo do Distrito Federal e os dois primeiros nacionais (1950 e 1960) usavam o termo favela, o Censo de 1970 já empregou o termo "aglomerados urbanos excepcionais" para designar os espaços favelados, enquanto o Censo de 1980 utilizou a expressão "aglomerados especiais urbanos" e, a partir do Censo de 1991, o termo aglomerados subnormais vem sendo aplicado para designar tais espaços. A evolução desse conceito revela o esforço do IBGE de construir uma designação que possa abarcar a diversidade de expressões para esses espaços no país. É uma pena, no entanto, que a designação
112. Ibid., p. 4.

113. Para Roberta Ferreira, moradora do Borel: "O programa favela-Bairro trouxe asfalto e melhorias para alguns pontos, mas convivemos com risco de deslizamento de encostas, esgoto correndo a céu aberto e outros problemas. Para deixarmos de ser favela, ainda vai demorar" (O Globo, 30 maio 2011). 
atual, aglomerados subnormais, seja tão negativa, reforçando a ideia de uma hierarquia entre as favelas e os demais bairros da cidade.

Identificamos, também, as alterações no conteúdo das definições desses espaços. Há um esforço, como observamos, de considerar como favela os aglomerados que apresentem certa densidade, o que parece justificar o fato dos censos terem sempre estabelecido, com exceção do Censo de 1960, uma proporção mínima de mais de 50 habitações para considerar um espaço como favela. Apesar das alterações das definições com o tempo, elas sempre identificaram as favelas pelo princípio da ausência das características passíveis de considerar tais espaços como parte integrante da cidade (precariedade das construções, ausência de serviços públicos ou inexistência de tífulos de propriedade). Da mesma forma, tais definições acabaram homogeneizando o entendimento sobre tais espaços e levaram, inclusive, mais recentemente, a um questionamento por parte da prefeitura do Rio de Janeiro.

A observação desses conceitos permite também compreender a evolução das políiticas públicas com relação às favelas. O Censo de 1980, por exemplo, já dá um peso menor à pretensa falta de equipamentos públicos nesses espaços, refletindo a mudança das políticas públicas referentes às favelas após os primeiros projetos de urbanização de favelas do final dos anos 1970. A partir do Censo de 1991, por sua vez, já é possível identificar certa relativização da questão jurídica, o que reflete o impacto das políticas, que vinham sendo implementadas para a regularização fundiária dessas áreas. As mudanças das definições de favelas levantavam, assim, a questão se/e como determinado espaço poderia não mais ser considerado como favela.

Procuramos, ainda, apontar questões técnicas que foram levantadas pelos censos para responder às particularidades da realidade das favelas. Um elemento importante se baseia sobre a ausência de endereçamento das casas nas favelas. Os censos não poderiam se basear em cadastros existentes, mas construir estratégias para atingir o conjunto de construções sem sobrepor ou negligenciar certos setores das favelas. Esse esforço se manifestou, assim, em técnicas de mapeamento, que evoluíram desde croquis, realizados pelas equipes de recenseadores do Censo de 1950, até a utilização de imagens de satélite de alta resolução e de um trabalho mais próximo aos órgãos municipais de urbanismo durante o Censo de 2010.

Se a evolução dos conceitos sobre os espaços favelados reflete as alterações ocorridas nesses espaços, as estratégias do serviço censitário também refletem as alterações societárias dessas áreas, como, por exemplo, a previsão, na ficha do Censo de 2010, de informações, por parte dos recenseadores, sobre a segurança de acesso às áreas faveladas. Observa-se, por fim, a importância do censo para o governo desses espaços, como, por exemplo, a inclusão, no Censo de 2000, na Caderneta do Setor e na Folha de Coleta, questões referentes a existência ou não 
de serviços e equipamentos públicos para auxiliar a formulação de políticas públicas para esses espaços. Ao longo dos anos, como pontuamos nesse artigo, os censos ao mesmo tempo que se adaptaram à evolução das favelas, contribuíram na própria definição desses espaços e na formulação de políicas públicas ali implementadas. 


\section{REFERÊNCIAS}

FONTES IMPRESSAS

AGACHE, Alfred. Cidade do Rio de Janeiro, remodelação, extensão e embelezamento. Paris: Foyer Brésilien, 1930.

CÂMARA do Distrito Federal. Anais da Câmara do Distrito Federal (setembro de 1948). Rio de Janeiro: Câmara do Distrito Federal, 1948.

CAVAlIERI, Fernando; VIAL, Fernanda. A nova Classificação de favelas para o planejamento das políticas públicas. Rio de Janeiro: IPP, 2012. Disponível em: <https:// bit.ly/2ZbGDdc>. Acesso em: dez. 2019.

CAVAlIERI, Fernando; VIAL, Fernanda. Favelas na cidade do Rio de Janeiro: o quadro populacional com base no Censo 2010. Rio de Janeiro: IPP, 2012.

CEASM. Quem somos? Quantos somos? O que fazemos? A maré em dados: censo 2000. Rio de Janeiro: CEASM, 2003.

DEPARTAMENTO de Estatística e Publicidade. Estatística Predial do Distrito Federal de 1933. Rio de Janeiro: Departamento de Estatística e Publicidade, 1935.

DIRECTORIA Geral de Estatística, Recenseamento do Brazil. Estatística predial e domiciliária da cidade do Rio de Janeiro. Rio de Janeiro: Typologia da Estatística, 1925.

FERREIRA, Maria Paula et al. Uma metodologia para a estimação de assentamentos precários em nível nacional. São Paulo, 2007. Mimeografado. Disponível em: <https://bit. ly/2AJOUvs>. Acesso em: mar. 2019.

IBGE. Censo demográfico de 1960. Favelas do Estado da Guanabara VII recenseamento geral do Brasil (Série Especial, v. IV). Rio de Janeiro: IBGE, 1960.

IBGE. VIII Recenseamento Geral/1970 (Série Regional, v. I, t. XVI). IBGE: Rio de Janeiro, $1970 \mathrm{a}$.

IBGE. VIII Recenseamento Geral. Instruções para delimitação dos setores censitários. Rio de Janeiro: IBGE, $1970 \mathrm{~b}$. 
IBGE. A base territorial dos censos de 1980. Rio de Janeiro: IBGE, 1981.

IBGE. IX Recenseamento Geral do Brasil-1980. Censo demográfico, dados gerais - Migração, instrução, fecundidade, mortalidade - Rio de Janeiro (v. 1, t. 4, n. 18). Rio de Janeiro: IBGE, 1983.

IBGE. Censo demográfico de 1991. Resultados do universo relativos às características da população e dos domicílios. Rio de Janeiro: IBGE, 1991.

IBGE. Metodologia do Censo Demográfico 2000 (Série Relatórios Metodológicos, v. 25). Rio de Janeiro: IBGE, 2003.

IBGE. Aglomerados Subnormais. Levantamento de Informações Territoriais. Referências Básicas (Segundo Encontro Nacional de chefes de Agências do IBGE). Angra dos Reis: IBGE, 2009.

IBGE. Censo Demográfico de 2010. Aglomerados subnormais, primeiros resultados. Rio de Janeiro: IBGE, 2010.

IBGE. Metodologia do censo demográfico 2010. Rio de Janeiro: IBGE, 2016 (série Relatórios metodológicos, v. 41).

MARQUES, Eduardo (coord.). Assentamentos precários no Brasil Urbano. Brasília: Centro de Estudos da metrópoles e Ministérios das Cidades, 2007.

MATION, Lucas Ferreira; NADALIN, Vanessa Gapriotti; KRAUSE, Cleandro. Favelização no Brasil entre 2000 e 2010: Resultados de uma classificação comparável. Rio de Janeiro: Ipea, 2014.

OFFICINA de Estatística. Recenseamento do Rio de Janeiro de 1906 (Districto Federal). Rio de Janeiro: Officina da Estatística, 1926.

OLIVEIRA, Jane Souto; NIEMEYER, Lilian de Jesus Garcia. Reavaliação das favelas do município do Rio de Janeiro. Rio de Janeiro: [s. n.], 1983. Mimeografado.

PREFEITURA do Distrito Federal. Censo das favelas. Aspectos gerais. Rio de Janeiro: Departamento de Geografia e Estatística, 1949.

REDES DA MARÉ. Censo Populacional da Maré. Rio de Janeiro: Redes da Maré, 2019. 
RIO DE JANEIRO. Plano Diretor. Lei Complementar $n .111$ de $1^{\circ}$ de fevereiro de 2011. Dispõe sobre a política Urbana e Ambiental do Município, institui o Plano Diretor de Desenvolvimento Urbano Sustentável do Município do Rio de Janeiro e dá outras providências. Rio de Janeiro, 2011. Disponível em: <https://bit.ly/2O8qFdA>. Acesso em: 18 jul. 2018.

LIVROS, ARTIGOS E TESES

ANJOS, Gabriele dos. A questão "cor" ou "raça" nos censos nacionais. Indic. Econ. FEE, v. 41, n. 1, p.103-118, 2013.

BOMFIM, Paulo Roberto de Albuquerque. Teoria e prática do planejamento regional no IBGE na década de 1960. Terra Brasilis (Nova Série) [on-line], nº 3, 2014. Disponível em: <https://bit.ly/3iQEtaA>. Acesso em: dez. 2019.

CAVALCANTI, Mariana. Vida e Morte do "Agrupamento 26" (2011-2013): breve etnografia do Morar Carioca na "Barra Olímpica". Revista de Antropologia, v. 60, n. 3, p. 211-235, 2017.

CAVAlIERI, Fernando et al. Caracterização e tipologia dos assentamentos precários brasileiros: o caso do Rio de Janeiro. In: MORAIS, Maria da Piedade; KRAUSE, Cleandro; LIMA NETO, Vicente Correia (orgs.). Caracterização e tipologia de assentamentos precários: estudos de caso brasileiros. Brasília: Ipea, 2016. p. 411-463.

COSTA PINTO, Luiz de Aguiar. O Negro no Rio de Janeiro: Relações de Raças numa Sociedade em Mudança. São Paulo: Companhia Editora Nacional, 1953.

COSTA, Valéria Grace. Rediscutindo o espaço-favela: sobre a operacionalização da pesquisa em favelas - o caso do Município do Rio de Janeiro. Revista Brasileira de Geografia, v. 58, n. 1/4, p. 25-36, 1996.

COSTA, Valéria Grace; NASCIMENTO, Jose Antonio Sena do. O conceito de favelas e assemelhados sob o olhar do IBGE, das prefeituras do Brasil e da ONU. Anais do $X$ Encontro de Geógrafos da América Latina, São Paulo, p. 3794-3808, mar. 2005.

DESROSIERES, Alain; KOTT, Sandrine. Quantifier. Genèses, nº 58, p. 2-3, 2005.

GONÇALVES, Rafael Soares. Favelas do Rio de Janeiro. História e Direito. Rio de Janeiro: Palas, 2013. 
GUERREIRO, Maria Pandolfi. Dilemas para a consolidação de uma política pública territorial: um debate sobre a UPP Social. Tese (doutorado em Políticas Públicas, Estratégias e Desenvolvimento) - Departamento de Economia, Universidade Federal do Rio de Janeiro, 2019 (versão preliminar apresentada à banca).

GUimarães, Alberto Passos. As favelas do Distrito Federal. Revista Brasileira de Estatística, no 55 , p. 250-278, 1953.

MAIO, Marcos Chor. Uma Polêmica Esquecida: Costa Pinto, Guerreiro Ramos e o Tema das Relações Raciais. Dados, v. 40, n. 1, p.127-162, 1997.

MARTIN, Olivier. Chiffrer pour évaluer? [on-line]. La vie des idées, 2016. Disponível em: $<$ https://bit.ly/38VeMkV>. Acesso em: dez. 2019.

MOTTA, Eugenia. Resistência aos números: a favela como realidade (in) quantificável. Mana, n. 25, p. 72-94, 2019.

OLIVEIRA, Samuel Silva Rodrigues de; "Trabalbadores Favelados": identificação das favelas e movimentos sociais no Rio de Janeiro e em Belo Horizonte. 2014. Tese (doutorado em História) - Fundação Getulio Vargas, Rio de Janeiro, 2014.

PARISSE, Lucien. Favelas de l'agglomération de Rio de Janeiro. 1970. Tese (doutorado Zème Cycle) - Universidade de Estrasburgo, Estrasburgo, 1970, 217p.

PIZA, Edith; ROSEMBERG, Fúlvia. Cor nos censos brasileiros. Revista USP, n. 40, p. 122-137, 1998.

RUIZ, Émilien. Légitimer par les nombres, à propos d'une autre fonction des outils quantitatifs. Statistique et société, v. 6, n. 1, p. 21-25, 2018.

SENRA, Nelson. Pesquisa histórica das estatísticas: temas e fontes. Revista História, Ciências, Saúde, v. 15, n. 2, p. 411-425, 2008.

SILVA, Maria Laís Pereira da. Favelas Cariocas (1930-1964). Rio de Janeiro: Contraponto, 2005.

SILVA, Jailson de Souza (org.). O que é favela, afinal?. Rio de Janeiro: Observatório de Favelas do Rio de Janerio, 2009.

TASCHNER, Suzana. Favelas em São Paulo - censos, consensos e contra-sensos. Trabalho apresentado no Encontro da Anpocs. Caxambu: [s. n.], 2000. Mimeografado. 
Artigo apresentado em 15/12/2019. Aprovado em 29/5/2020.

\section{(cc) BY}

All the contents of this journal, except where otherwise noted, is licensed under a Creative Commons Attribution Licens 